ORIGINAL ARTICLE

\title{
Mental illness and cultural issues in West African films: implications for orthodox psychiatric practice
}

\author{
O F Aina
}

J Med Ethics; Medical Humanities 2004;30:23-26. doi: 10.1136/jmh.2003.000152

The portrayal of psychiatry and of the activities of supernatural forces in indigenous films produced in West Africa was critically examined in this study. Most often the content of these films is centred on African culture, African mythical stories, or real life events. Over a three year period, 163 such films were studied. Twenty five $(15.3 \%)$ of them contained scenes of psychiatric illness. In 24 of these, there were "cases of psychoses"; and the remaining one was that of "deliberate self harm" via overdose with hypno-sedative drug. The causative factors of these "illnesses" were largely attributed to supernatural or preternatural forces. The effective treatment or "healing" of the illnesses was portrayed as arising mostly through magical means or traditional forms of care. In addition, sudden death from "spiritual attack" by these agents was shown in $35(21.5 \%)$ of the films. Scenes of witches and occultists wreaking other forms of havoc on victims at night were shown in eight $(4.9 \%)$ of the films. The implications of these films' portrayals of psychiatry and supernatural forces for the public (particularly viewers with mental illness) and for orthodox psychiatric practice in the region were highlighted.

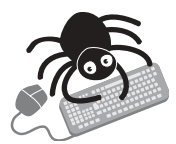

The appendices listing the films can be found on the JMH website (www. medicalhumanities.com/ supplemental)

Correspondence to: Dr O F Aina, Department of Psychiatry, College of Medicine, University of Lagos, PMB 12003, Lagos, Nigeria; ainafran@yahoo. com

Accepted for publication 14 February 2004 contrary and most African scholars asserted that despite the influence of these religions and Western civilisation, the real test comes in times of trouble, including illness, when a large percentage of Africans-irrespective of their educational level-still consult traditional healers and spiritualists for guidance. ${ }^{14}$

In the past few years, one of the notable reinforcing factors of the belief in magical concepts of mental illness and death in West Africa is the unfortunate upsurge in the broadcast of these beliefs over the electronic media. Historically, psychiatry began to appear in the mass media of the Western world in the 1940s; and specifically television started to provide information (although largely negative) about mental health to the public in the 1950s. ${ }^{78} \mathrm{~A}$ few films, notably The Snake Pit, showed the psychiatrically ill to be violent and malicious, often being treated as other than human. ${ }^{7}$ But, despite this stigmatising influence, the mass media continue to be an important source of public information on mental health issues, shaping people's attitudes towards mental illness. In particular, quite a number of people worldwide are keen on watching films and TV broadcasts, and observations in West Africa have shown that the granting of operating licences for private TV broadcasting almost 10 years ago in some countries, such as Nigeria and Ghana, has led to an astronomical growth in the indigenous TV and film industries. ${ }^{9}$ For example notable television stations in the African continent such as "TV Africa" broadcast some programmes including indigenous films (between 20.00 and 23.00 hours) over a wide area through local TV stations in various countries in the region. Much concern is however being expressed over the resultant uncensored production, marketing, and broadcasting of these films, negatively portraying African traditional or cultural beliefs, most especially those about mental illnesses and death. ${ }^{10}$ Despite this concern from some quarters, there has been a huge growth in interest in watching these films and related TV programmes among the public. ${ }^{11}$ Main streets in some cities and towns in the region are adorned with colourful posters, almost on a weekly basis, announcing the arrival of new films onto the market, and there is continuous proliferation of retail and rental outlets that are heavily used by the public. ${ }^{12}$ Furthermore, in the course of clinical practice, I have encountered patients and their relatives attributing mental illness to supernatural forces and quoting the films they watched as one of the sources of their information. This erroneous belief usually makes it 
difficult for the patients to gain the required insight, with subsequent poor compliance with treatment. Therefore, this study set out to critically evaluate psychiatric illness and related cultural issues as portrayed in West African indigenous films. Their implications for the public perception of psychiatry, health seeking behaviour of patients with mental illness or their caring relatives, and orthodox psychiatric practice in the region are highlighted.

\section{METHOD}

The study took place in Lagos, the commercial capital of Nigeria. Lagos is the most populous city in West Africa with the latest estimate of 13.4 million people in the year 2000; and about 600000 people migrate to the city every year, thereby making it one of the fastest growing cities in the world, ${ }^{13}$ with residents from virtually every tribe in the country reasonably well represented, and immigrants from neighbouring countries such as Benin Republic, Togo, Ghana, and so on. In West Africa, Lagos has the highest concentration of 10 television stations (seven of them are owned by private individuals and the other three by the government); and the largest indigenous film market in the region is located in the city. ${ }^{11}{ }^{12}$ Other major market outlets for these films in the region are the cities of Accra, Kumasi (Ghana), Freetown (Sierra-Leone), Monrovia (Liberia), Ibadan, Kano, Port-Harcourt, (Nigeria).

The films included in this study were those produced in Yoruba (the local language in southwestern Nigeria) and English, the two languages best understood by the author; and the sources included:

(1) Indigenous films purchased or rented from different well stocked retail outlets in the metropolis. At such outlets, systematic random sampling was used to select the films for study. Each of these films was attentively watched in turn.

(2) Indigenous films aired over the various TV stations-for example, "African Independent Television" (AIT), "TV Africa", "Nigerian Television Authority" (NTA).

In all, broadcasts from $11 \mathrm{TV}$ stations were received in the study centre, with very clear pictures and quality sound. The daily transmission schedules for these TV stations were studied to know the days in the week and period of the day these films were transmitted. Five $(45.5 \%, \mathrm{n}=11)$ of these TV stations regularly transmit indigenous films most days of the week from 22.00 or 23.00 hours.

The exclusion criteria were: partially watched films from TV broadcast due to a break in transmission resulting from power loss and films produced in languages/local dialects not well understood by the author. For the films eventually studied, detailed notes of their message and predominant tone were made on each of them immediately following attentive viewing.

\section{RESULTS}

A total of 163 West African films (films produced in West Africa for a West African audience) were studied during the 36 month period.

\section{Contextual analysis of the films \\ Mental illness}

Twenty five $(15.3 \%, \mathrm{n}=163)$ of these films depicted prominent scenes of a character as mentally ill. The symptomatic manifestations in 24 of these films were those of a vagrant and psychotic state. The "victims" exhibited personality deterioration (generally unkempt and neglect of personal hygiene), roaming behaviour, picking from the refuse dumps to eat or hoard. Other "symptoms" included talking and/or laughing to oneself while alone, irrelevant gesticulation and, sometimes, unprovoked verbal and/or physical aggression. In the remaining one of these films was a "case" of deliberate self harm via overdose with hypnosedative drugs following a disappointment in love. On the whole, only a few $(15.3 \%)$ of the films showed scenes of mental illnesses, with $\chi^{2}$ of $78.34(\mathrm{p}<0.05)$.

However, the attributed causes of mental illness as portrayed in the films included the following:

- Affliction from sorcery, witchcraft, and charms, 15 (60.0\% $\mathrm{n}=25$ ). For example, the actor shown to be psychotic in the film Attack From Home became ill after a charm prepared by invoking his name was dropped by his enemy into a stream that serves as the source of water supply in his home village.

- Overwhelming psychosocial stressors, six $(24.0 \%, \mathrm{n}=25)$. For example, in the films Remember and Scores to Settle.

- Curses from enemies and offended deities or gods, three $(12.0 \%, \mathrm{n}=25)$. For example, in the film Egun Aimo (acted in Yoruba language and translated to mean "Unknown Curse"), the actor that had "psychotic disorder" became ill from the effect of a curse invoked on his late father by his enemy.

- Polysubstance dependence, one $(4.0 \%, \mathrm{n}=25)$ (table $\mathrm{l}$ and appendix I; see www.medicalhumanities.com/ supplemental).

Concerning treatment modalities, no attempt to treat the "victims" was shown in $13(52 \%)$ of the films that depicted scenes of mental illness. In the remaining 12 (48\%) treatments were sought, with greater effectiveness ascribed to alternative therapies of traditional and spiritual healings in 10 cases $(40 \%)$ compared with orthodox hospital care of two cases $(8 \%)$. Hence, as portrayed in the films, there is a significant statistical difference in terms of the effectiveness between the orthodox hospital care and alternative therapies-that is, the latter greater than the former with $\chi^{2}$ of $9.32(\mathrm{p}<0.05)$.

Closely related to mental illness were scenes of prominent visual and auditory hallucinations in two of the films (Ojo Aiku and Captives of the Mighty, respectively). In both of these films, an actress was shown to be married to a "husband" in the spirit world; and only the actress could see and converse with the husband. Thus, such acts appeared to other people around her in the real physical world as visual and auditory forms of hallucination.

\section{Unexpected, sudden death}

In 35 of the films $(21.5 \%, \mathrm{n}=163)$ characters were shown to have died suddenly and unexpectedly via "spiritual attacks" from gods/deities, sorcerers, witches, ghosts, or evil spirits. Other causes of death included being charmed by enemies, ritualistic death, and curses (table 2 and appendix II; see www.medicalhumanities.com/supplemental).

\begin{tabular}{|c|c|c|}
\hline Causes & Number & (\%) \\
\hline Sorcery and enchantment & 15 & 60.0 \\
\hline Overwhelming life stressors & 6 & 24.0 \\
\hline Curses from the deities or enemies & 3 & 12.0 \\
\hline Polysubstance dependence & 1 & 4.0 \\
\hline Total & $25^{*}$ & 100.0 \\
\hline
\end{tabular}


Table 2 Causes of sudden unexpected deaths as portrayed in the films

\begin{tabular}{lcr}
\hline Causes & Number & \multicolumn{1}{c}{$(\%)$} \\
\hline Spiritual attacks by: & & \\
$\quad$ sorcerers & 8 & 22.9 \\
gods/dieties & 5 & 14.4 \\
witches & 3 & 8.5 \\
ghosts/evil spirits & 3 & 8.5 \\
Money making rituals & 8 & 22.9 \\
Enchantment/charmed by the enemies & 6 & 17.1 \\
Curses & 2 & 5.7 \\
Total & 35 & 100.0 \\
\hline
\end{tabular}

Nocturnal activities of witches and occultists Lastly, scenes of witches or occultists meeting in the dead of night to wreak havoc or death on people were shown in eight $(4.9 \%)$ of the films (appendix III; see www.medicalhumanities. com/supplemental).

\section{DISCUSSION}

As shown in the study, psychiatry and the harmful effects of supernatural forces are portrayed in films produced in West Africa. In all but one of the 25 films showing scenes of psychiatric illness, the illness was portrayed only in the form of psychoses, with vagrancy, and with or without violent behaviour. In a way, this could be a reflection of the public understanding in Africa of how mental illness can usually manifest itself; hence, neurotic patients with intact personality may not be seen as mentally ill. This erroneous portrayal of psychiatric illness in the media has become an issue of concern, and evidence from other studies has shown that such media portrayal correlates with public opinion. ${ }^{14}$ Particularly in Africa where there is still a lot of stigmatisation surrounding psychiatry, ${ }^{13}$ the rejuvenation of such misconceptions about psychiatric illness via communication facilities such as films can further deepen the stigmatisation of the psychiatrically ill in the community. In essence, it shows that a lot still needs to be done in terms of public health education to reduce, if not eliminate, the stigmatising of mental illness in this society.

Furthermore, in over $70 \%$ of the films depicting mental illness, the apparent causes were supernatural factors such as spiritual attacks from sorcery, witchcraft, enchantment and curses from enemies, gods, or deities, and so on. This largely erroneous portrayal is in line with the general belief in the wider African society regarding the causes of mental illness. ${ }^{145}$ This fact might be partly responsible for the relatively high uptake for far less effective traditional care compared with orthodox psychiatric treatment. No attempt to treat mental illness was shown in over half of the films examined, and this could probably reflect the unfortunate and widely held notion in Africa that most cases of psychiatric disorders have no cure. ${ }^{315}{ }^{16}$ However, for those shown to have been treated, emphasis was placed on the effectiveness of healing via spiritual intervention of prayer, fasting, and "deliverance sessions" to cast out any implicated demons, as well as traditional treatment involving incantations, use of herbal concoction, and sacrifices to appease the enemies and/or the offended gods or deities. This is in line with the well known fact that in Africa, traditional healers and spiritualists still enjoy large patronage for mental health care, ${ }^{1516}$ probably borne out of the perceived causative factors mentioned previously. On the other hand orthodox hospital care was, erroneously, shown to be largely ineffective. Hence this could discourage people from seeking orthodox care for mentally ill patients in this region. In clinical practice in Africa, the use of largely ineffective traditional care before psychotic patients are finally brought to hospital sometimes results in cases becoming chronic. However, it is hoped that the appropriate authorities will increase health educational campaigns to encourage early orthodox psychiatric consultation for those with mental illness.

The super/preternatural causation of sudden, unexpected death, and frightening scenes of witches and occultists meeting under the cover of night to perpetrate harm on people, as portrayed in nearly $25 \%(n=163)$ of the films, is a significant reflection of African beliefs. For instance, in these films some of the causes of sudden, unexpected deaths included being sorcerised, calling the name of the victim thrice unto a charm, or even shooting the picture of the victim following some incantations on the picture. In Africa, a lot of life misfortunes and questionable deaths are attributable to the subtle manipulation of the witches, sorcerers, demons, and so on, and it is a taboo to discuss them openly for fear of reprisal attacks. ${ }^{2}{ }^{4}$ Thus, a lot of unexpressed fear for these supernatural forces pervades the mind of most Africans irrespective of their educational level. It is therefore important to note that the types of phobia seen in the Western world are not rare in Africa; rather, phobic cases present with pathological fear of these forces, usually accompanied with functional somatic complaints. ${ }^{17}$

Finally, despite the well known misrepresentation of psychiatry in the media, the credibility the society grants to this forum can be exploited to the advantage of psychiatric profession especially using the audiovisual media with a high sense of appeal to change the present negative attitude of the society as much as possible. ${ }^{18}$ It is gratifying to note that the National Film and Video Censors Board in Nigeria, in collaboration with its counterpart in Ghana, has recently stepped up efforts to sanitise and regulate the film industry in the region. In the course of doing this, some indigenous films have been banned from being broadcast over the mass media, whereas some others have been guidance rated for viewing according to age. ${ }^{10}{ }^{19}$ All these regulatory activities are aimed to curtail the misrepresentations of African tradition, especially where it affects (mental) health and death.

In conclusion, the present portrayal of psychiatry in indigenous films in West Africa is rather erroneous and reflective of the superstitious beliefs of the people. However, the passion to watch films can be exploited to produce health promotional films that appropriately educate the public on mental health and psychiatric illnesses.

\section{ACKNOWLEDGEMENTS}

The author is grateful to all the film retail outlets and video clubs used in this study. The author's sincere thanks also go to the critics of the earlier draft of this manuscript; and to Mr Gbenro Samuel for his secretarial assistance.

\section{REFERENCES}

1 Odejide AO, Oyewumi LK, Ohaeri JU. Psychiatry in Africa: An overview. Am J Psychiatry 1989;146:708-16.

2 Morakinyo O, Akiwowo A. The Yoruba ontology of personality and motivation. A multidisciplinary study. Journal of Social Biology and Structure $1981 ; 4: 19-38$

3 Asuni T, Wolff NH. The prevalence of belief in indigenous medicine among yoruba mental patients. Baltimore, Maryland, USA: Paper presented at the 21 st annual meeting of the Africa studies Association, 1978.

4 Makinde MA. Cultural and philosophical dimensions of Neuromedical Sciences. Nigerian Journal of Psychiatry 1985;1:85-100.

5 Field MJ. Witchcraft as a primitive interpretation of mental disorder. J Ment Sci 1955;101:826-33.

6 Simpson GE, ed. Changes in Yoruba Religion and Medicine. In: Yoruba religion and medicine in Ibadan. University of Ibadan, Nigeria: Ibadan University Press, 1980:143-69. 
7 Freeman $\mathbf{H}$, Wahl OF, Jakab I, et al. Mass media and psychiatry: commentaries. Current Opin Psychiatry 2001;14:529-35.

8 Philo G. Media images and popular beliefs. Psychiatric Bulletin 1994; 18:489-91.

9 Obasi NK. Evolution of the broadcast media in Nigeria. In: Ajaegbu HI, St Mathew-Daniels BJ, Uya OE, eds. Nigeria: a people united, a future assured. A compendium. Calabar, Nigeria: Guabumo publishing Co Ltd, 2000:373-7

10 Akpovi-Esade J. Movies: battle on the classification turf. In: Adesina D, ed. The Guardian [Friday October 11, 2002]. Isolo, Lagos, Nigeria: Guardian Newspapers Publishing Ltd, 2002:26-7.

11 Husseini S. Deep passions for the movie up north. In: Adesina D, ed. The Guardian [Friday October 18, 2002]. Isolo, Lagos, Nigeria: Guardian Newspapers Ltd, 2002:27-8.

12 Dayo - Aiyetan K. Indigenous film industry booms. In: Ishiekwene A, ed. Sunday Punch [November 17, 2002]. Ikeja, Lagos: The Punch Nigeria Limited Publishing Company, 2002:36.

13 Tibaijuka AK. Lagos Megacity: Tackling the challenges of economic development. A paper presented by the Executive director of United Nations
Human Settlement Programme (UN-HABITAT) at the Third Lagos State Economic Summit "Ehingbeti 2002"; September 2002.

14 Wahl O, Roth R. Television images of mental illness: Results of a metropolitan Washington media watch. Journal of Broadcasting 1982;26:599-615.

15 Prince R. Some notes on Native doctors and their management of mental illness. In: Lambo TA, ed. First Pan African Psychiatric conference, Ibadan. Ibadan, Western Region, Nigeria: Government Printer, 1962

16 Ebigbo PO, Tyodza W. Healing methods of a prayer house in Nigeria. In: Erinosho OA, Bell NW, eds. Mental Health in Africa. Ibadan, Nigeria: Ibadan University Press, 1982.

17 Morakinyo O. Phobic states presenting as somatic complaints syndromes in Nigeria: Socio-cultural factors associated with diagnosis and psychotherapy. Acta psychiatrica Scandinavica 1985;71:356-65.

18 Philo G. Changing media representations of mental health. Psychiatric Bulletin 1997;21:171-2.

19 Bardi JN. The video in the cleaning room. In: Adesina D, ed. The Guardian, [Friday, December 6, 2002]. Isolo, Lagos, Nigeria: Guardian Newspapers Ltd, 2002:29. 